\title{
DESENVOLVIMENTO SUSTENTÁVEL COMO DIREITO FUNDAMENTAL E O PRINCÍPIO DA DIGNIDADE DA PESSOA HUMANA
}

\begin{abstract}
Gabriel Wedy
Juiz Federal. Doutor e Mestre em Direito Ambiental pela PUCRS, onde é professor convidado no curso de especialização de direito público e pós-doutorando, com estágio doutoral na Columbia Law School. Visiting Scholar pela Columbia Law School (Sabin Center for Climate Change Law). Professor Coordenador da disciplina de Direito Ambiental na Escola Superior da Magistratura Federal - ESMAFERS com sede em Porto Alegre. Foi Presidente da Associação dos Juízes Federais do Brasil - AJUFE e da Associação dos Juízes Federais do Rio Grande do Sul - AJUFERGS-ESMAFE. Autor de diversos artigos na área do direito ambiental no Brasil e no exterior e, entre outros, do livro $O$ princípio constitucional da precaução como instrumento de tutela da saúde pública e do meio ambiente.
\end{abstract}

\begin{abstract}
Resumo: No artigo, são abordados o princípio da dignidade da pessoa humana e a sua evolução histórica desde os primórdios da humanidade, passando pela Idade Média, Modernidade e PósModernidade. O princípio é analisado criticamente com base em consagrada doutrina e jurisprudência estrangeira para somente após ser avaliado com base em doutrina nacional, tendo como pano de fundo, então, leading cases do Supremo Tribunal Federal. Fixados os seus parâmetros, o princípio da dignidade da pessoa humana é apontado como relevante para a concretização do direito fundamental ao desenvolvimento sustentável no seu pilar humano (de inclusão social). É enfatizado que existe, nos países em desenvolvimento, como o Brasil, desequilíbrio entre desenvolvimento econômico, desenvolvimento humano, proteção ambiental e governança. O princípio da dignidade da pessoa humana, nesse cenário de insustentabilidade, acaba sempre por ser essencial na promoção do desenvolvimento. No texto, é defendida a tese, como apoio em doutrina e jurisprudência nacional e estrangeira, de que não existe direito fundamental ao desenvolvimento sustentável, passível de concretização, sem o respeito ao princípio norteador da dignidade da pessoa humana, que promove e estimula a inclusão social e serve como promotor e garantidor dos direitos fundamentais.
\end{abstract}

Palavras-chave: Direito constitucional. Princípio. Dignidade da pessoa humana. Direito e desenvolvimento.

Sumário: 1 Introdução - 2 A dignidade da pessoa humana e a sua evolução histórica - 3 A dignidade da pessoa humana na jurisprudência estrangeira - $4 \mathrm{~A}$ dignidade da pessoa humana sob a égide da Constituição Federal de 1988 - 5 A jurisprudência do STF sobre dignidade da pessoa humana 6 Dignidade da pessoa humana e desenvolvimento sustentável - 7 Conclusão - Referências 


\section{Introdução}

O pilar humano (de inclusão social) do direito fundamental ao desenvolvimento sustentável está intrinsicamente ligado ao princípio da dignidade da pessoa humana. É mandatória, portanto, a análise do princípio da dignidade da pessoa humana em todas as suas dimensões, buscando suas raízes históricas, com a análise da evolução do princípio ao longo do tempo. Diplomas legais no âmbito internacional que consagraram o princípio e os julgados que o tem densificado e normatizado precisam ser identificados para a solidificação e a garantia de consistência do presente artigo. A preferência, neste ponto, recairá sobre leading cases provenientes da jurisprudência alemã, francesa e norte-americana, pela importância que possuem esses países no âmbito do direito constitucional.

Importante contextualizar o princípio da dignidade da pessoa humana na Constituição Federal de 1988, com base em doutrina nacional, para, também, verificar a jurisprudência do STF concernente ao tema. ${ }^{1}$

\section{Dignidade da pessoa humana e a sua evolução histórica}

O conceito de dignidade da pessoa humana, ainda que de modo rudimentar, encontra registro desde os primórdios da humanidade. Basta observar os escritos do Gênesis, na Bíblia Sagrada:

Deus criou o ser humano à sua imagem, à imagem de Deus o criou, macho e fêmea ele os criou. E Deus os abençoou e Ihes disse: "Sede fecundos e multiplicai-vos, enchei a terra e submetei-a! Dominai sobre os peixes do mar, as aves do céu e tudo o que vive e se move sobre a terra". ${ }^{2}$

Essa visão antropocêntrica, colocando o homem no epicentro do Universo, está expressa no texto bíblico, que diz com todas as letras que o homem foi criado, embora não como um Deus, à sua imagem e semelhança.

Acadêmicos tendem a ser fortemente críticos em relação às decisões judiciais, e juízes tendem a ignorar advertências doutrinárias. Importante é a análise ponderada entre doutrina e jurisprudência. Sobre os caminhos divergentes entre a academia e o Poder Judiciário, ver: POSNER, Richard. Divergent paths. The academy and the judiciary. Cambridge: Harvard University Press, 2016. Ver também: POSNER, Richard. Reflections on judging. Cambridge: Harvard University Press, 2013. p. 329-350.

2 BíBLIA. Português. Bíblia sagrada. São Paulo: Folha de São Paulo, 2010. p. 13. (Coleção Folha: livros que mudaram o mundo, v. 18). 
A característica de uma visão centrada no ser humano prossegue no texto basilar da fé judaico-cristã: "Eis que vos dou todas as plantas que produzem semente e que existem sobre a terra, e todas as árvores que produzem fruto com semente, para vos servirem de alimento". E o Deus bíblico, após concluir o seu trabalho, em prol da humanidade, "descansou no sétimo dia de toda a obra que fizera". ${ }^{3}$

Após o indigno pecado original de Adão e Eva no paraíso, segundo a religião, a culpa imiscui-se na humanidade, e o humano pecador, por meio da fé em Deus e da expiação do pecado, passou a buscar o resgate de sua dignidade perdida.

0 tom calcado no sentimento de culpa, no pecado e na redenção do homem pela fé não é diferente para os muçulmanos. No Alcorão Sagrado, nesta conhecida passagem, isso ficou bem demonstrado: "Ó humanos, em verdade, nós vos criamos de macho e fêmea e vos dividimos em povos e tribos para reconhecerdes uns aos outros. Sabei que o mais honrado, dentre vós, ante ALLah, é o mais temente. Sabei que ALLah é Sapientíssimo e está bem inteirado". ${ }^{4}$ A dignidade do ser humano era medida - e ainda o é -, no âmbito religioso, pela fé em Deus. ALLah, em conformidade com o Alcorão, é vigilante e sabe quem são aqueles que têm fé e honra e aqueles que não têm fé e, portanto, não têm honra, nem dignidade.

Nos primórdios da humanidade, destarte, a dignidade do homem era medida pela fé em Deus. Aquele que não tinha fé era um simples pagão, destituído de dignidade, isso em igual intensidade para judeus, muçulmanos ou cristãos (em especial pelas leituras do Velho Testamento). Deus estaria sempre vigilante e seria implacável com os seus filhos pecadores que não o temessem.

0 estrangeiro, por sua vez, nem em Roma, nem em Atenas, era dotado de dignidade, pois não podia ser proprietário ou casar-se. Os filhos de cidadãos romanos ou atenienses com estrangeiros eram considerados bastardos. Os estrangeiros também não podiam celebrar contratos ou herdar. ${ }^{5} \mathrm{Em}$ Roma, era considerado cidadão e digno de respeito aquele que honrava os mesmos deuses da cidade, estava inscrito no livro dos cidadãos e havia jurado que praticaria os cultos aos deuses e que combateria por eles. ${ }^{6} 0$ cidadão romano tinha uma situação privilegiada, quer no campo do direito privado, quer no campo do direito

3 BÍBLIA. Português. Bíblia sagrada. São Paulo: Folha de São Paulo, 2010. p. 13. (Coleção Folha: livros que mudaram o mundo, v. 18).

4 Ver: Al Hujjurat 49:13 em: ALCORÃo Sagrado. São Paulo: Folha de São Paulo, 2010. p. 312. (Coleção Folha: livros que mudaram o mundo, v. 19).

5 COULANGES, Fustel. A cidade antiga: estudo sobre o culto, o direito e as instituições da Grécia Antiga e de Roma. São Paulo: Bauru, 2009. p. 161.

6 COULANGES, Fustel. A cidade antiga: estudo sobre o culto, o direito e as instituições da Grécia Antiga e de Roma. São Paulo: Bauru, 2009. p. 159. 
público: no campo do direito privado, tinha o jus comercii, o jus connubii e o direito de agir em juízo, recorrendo à legis actio; no direito público, o cidadão tinha o jus suffragii, o jus honorum e o direito de servir nas legiões. ${ }^{7}$

O status pessoal do cidadão ou a importância do exercício de determinadas funções conferiam-Ihe a dignitas. O pensamento estoico, ao contrário, era de que todas as pessoas eram dotadas de igual dignidade e que, nessa outra perspectiva, a dignidade já era tomada por qualidade própria, como inerente aos seres humanos, estando vinculada à ideia de liberdade pessoal de cada indivíduo. ${ }^{8}$ Foi, no entanto, a partir das formulações de Cícero, que se desenvolveu uma compreensão de dignidade desvinculada do cargo ou da posição social, sendo possível reconhecer a coexistência de um sentido moral e sociopolítico de dignidade. ${ }^{9}$ Desde essa primeira utilização, o discurso de Cícero tem sido associado à razão e à capacidade do homem em tomar livremente decisões morais. ${ }^{10}$

É importante observar que, até a Idade Média, em um ambiente não secularizado, ${ }^{11}$ a dignidade humana confundia-se de modo permanente com a religião. Um marco do início do rompimento dessa visão, em 1468, foi o discurso de Picco, Conde de Mirandola, no sentido da emancipação da razão filosófica em relação à razão teológica. Neste discurso, Oração sobre a Dignidade do Homem, duramente criticado pela Igreja Católica e entendido como uma heresia, está estampada a busca do ser humano pelo conhecimento. ${ }^{12}$ Picco construiu uma "distinção entre o mundo natural e o mundo espiritual", estando o homem "no centro do mundo, pois é o próprio Deus que reconhece essa posição central"

CRETELLA JÚNIOR, José. Curso de direito romano. 15. ed. Rio de Janeiro: Forense, 1993. p. 102.

8 Ver: COMPARATO, Fábio Konder. A afirmação histórica dos direitos humanos. São Paulo: Saraiva, 1999. p. 421. Ver também: SARLET, Ingo. Comentários ao art. 1, inc. III, da CF/88. In: CANOTILHO, J. J. Gomes et al. (Coord.). Comentários à Constituição do Brasil. São Paulo: Saraiva: Almedina, 2013. p. 121.

9 SARLET, Ingo. Dignidade da pessoa humana e direitos fundamentais na Constituição Federal de 1988. 9. ed. Porto Alegre: Livraria do Advogado, 2012. p. 35-36.

10 BARROSO, Luís Roberto. A dignidade da pessoa humana no direito contemporâneo: a construção de um conceito à luz da jurisprudência. Belo Horizonte: Fórum, 2013. p. 16.

11 Catroga refere que as razões para situar uma das causas da secularização judaico-cristã podem ser resumidas em três: em primeiro lugar, a afirmação da transcendência de Deus implicou a autonomia do mundo natural e político; em segundo lugar, Javé foi definido como Deus móvel, que intervém na história por meio de acções específicas, e a sua aliança com o povo eleito também é histórica, ficando assim rompida a lógica circular do cosmos e insinuada a historização - que a Encarnação reforçou - das relações do homem com Deus, bem como a abertura de um campo de possibilidades para a assunção do indivíduo como ser livre e responsável no tempo; em terceiro lugar, a normatividade mosaica e a esperança escatológica no Juízo Final definiram o novo Deus como um Deus ético, fonte que incitou as consciências cristianizadas a racionalizarem os ditames da moral e a desenharem horizontes de expectativas que serão projectados no imanentismo histórico (CATROGA, Fernando. Entre Deuses e Césares: secularização, laicidade e religião civil. Coimbra: Almedina, 2006. p. 24-25).

12 MIRANDOLA, Giovanni Pico Della. A dignidade do homem. Lisboa: Edições 70, 1986. Ver, igualmente: MIRANDOLA, Giovanni Pico Della. Oratio de hominis dignitate. Disponível em: <http:www.wsu.edu: 8080 wldciv/world_civ_reader_1/pico.html>. Acesso em: 01 jan. 2016. 
do ser humano como "uma entidade que não é nem celeste, nem terrena, mas completamente livre para se autoconformar, tal como um artista ou um poeta, livre para dar forma à sua própria existência". E a velha doutrina do imago Dei começa a ser substancialmente "superada por uma visão do homem que, precisamente porque feito à imagem do seu criador, é também senhor do seu mundo". ${ }^{13}$

Entre outros contratualistas, posteriormente, pode-se atribuir especialmente à Kant a justificação moral para um conceito base para a dignidade da pessoa humana. O filósofo de Könisberg afirmou que uma pessoa não está sujeita a outras leis senão àquelas que atribui a si mesma (ou isoladamente ou, ao menos, juntamente com os outros). ${ }^{14} \mathrm{O}$ princípio supremo da doutrina dos costumes de Kant é o imperativo categórico, qual seja: "Age com base em uma máxima que pode também ter validade com uma lei universal". Qualquer máxima que não seja assim qualificada é contrária à moral. ${ }^{15} \mathrm{~A}$ ação, que está de acordo com o imperativo categórico, é aquela boa em si mesma, independentemente da finalidade a que se propõe ou de suas eventuais consequências e resultados. Está vinculada a princípios morais apriorísticos que, desde que observados, não levarão o homem a uma conduta equivocada e à tão temida irrisão moral. Dentro da ética proposta por Kant, é possível verificar noções claras de razão e dever. 0 indivíduo deve conter seus desejos, seus impulsos e suas paixões ${ }^{16}$ e descobrir qual a lei moral que deve pautar a sua conduta.

Refere Sandel que a teoria de Kant não se baseia na ideia de que somos donos de nós mesmos ou na afirmação de que nossa vida e nossa liberdade sejam um presente de Deus; ao contrário: parte da ideia de que somos seres racionais, merecedores de dignidade e respeito. ${ }^{17} \mathrm{E}$ o respeito à dignidade humana, para Kant, exige que tratemos as pessoas como um fim em si mesmas. Por isso, nessa concepção, é errado usar algumas pessoas em prol do bem-estar geral, como prega o utilitarismo..$^{18} \mathrm{Ou}$, como refere Weber, de maneira elucidativa, sobre

13 RIDOLA, Paolo. A dignidade humana e o "princípio liberdade" na cultura constitucional européia. Porto Alegre: Livraria do Advogado, 2014. p. 33.

14 KANT, Immanuel. A metafísica dos costumes. São Paulo: Folha de São Paulo, 2010. p. 47.

15 KANT, Immanuel. A metafísica dos costumes. São Paulo: Folha de São Paulo, 2010. p. 48.

16 Para Sandel: "Kant repudia o papel subalterno da razão. Para ele, a razão não é somente uma escrava das paixões. Se a razão fosse apenas isso, diz Kant, estaríamos melhor se optássemos pelos instintos. O conceito kantiano de razão - de razão prática, aquela que tem a ver com a moralidade - não é o de uma razão instrumental, e sim uma razão prática pura, que cria suas leis a priori, a despeito de quaisquer objetivos empíricos" (SANDEL, Michael. Justice: what's the right thing to do? New York: Farrar, Straus and Giroux, 2009. p. 118).

17 SANDEL, Michael. Justice: what's the right thing to do? New York: Farrar, Straus and Giroux, 2009. p. 104.

18 SANDEL, Michael. Justice: what's the right thing to do? New York: Farrar, Straus and Giroux, 2009. p. 110. Uma crítica mais consistente de Sandel sobre o utilitarismo pode ser verificada em: SANDEL, Michael. Liberalism and the limits of justice. 2nd ed. Cambridge: Cambridge University Press, 1998. 
a dignidade segundo Kant, "quem tem dignidade nunca pode ser considerado simplesmente como meio". ${ }^{19}$

Barroso, por seu turno, entende que as ideias de Kant referentes à dignidade da pessoa humana podem ser condensadas em uma única proposição, qual seja:

\begin{abstract}
[...] a conduta moral consiste em agir inspirado por uma máxima que possa ser convertida em lei universal; todo homem é um fim em si mesmo, e não deve ser instrumentalizado por projetos alheios; os seres humanos não têm preço nem podem ser substituídos, pois eles são dotados de um valor intrínseco absoluto, ao qual se dá o nome de dignidade. ${ }^{20}$
\end{abstract}

É justamente no pensamento de Kant que a doutrina jurídica mais expressiva nacional e estrangeira - ainda hoje "parece estar identificando as bases de uma fundamentação e, de certa forma, de uma conceituação da dignidade da pessoa humana".21

O Iluminismo e a secularização marcaram, com contribuição kantiana, uma visão independente de dignidade da pessoa humana, deslocada da fé religiosa, fundamentada na autonomia e no direito ao respeito do homem como um fim em si mesmo. Todavia, foi após as guerras mundiais, em especial a segunda, marcada pelas brutalidades do nacional-socialismo, que a humanidade se sentiu tocada pela necessária proteção do ser humano e de sua dignidade no plano internacional. Houve um "ressurgimento do constitucionalismo do segundo pósguerra marcado por documentos e jurisdições internacionais de defesa e garantia dos direitos humanos contra os Estados nacionais". ${ }^{22}$

Marco desse período histórico foi a Declaração Universal dos Direitos Humanos (ONU), de 10 de dezembro de 1948, que, já em seu preâmbulo, consagrou o princípio da dignidade da pessoa humana. E foi além ao dispor, em seu art. 1ํㅜ que "todos os seres humanos nascem livres e iguais em dignidade e em direitos. Dotados de razão e de consciência, devem agir uns para com os outros em espírito de fraternidade". ${ }^{23}$ Após tal marco, vários tratados de direitos

19 WEBER, Thadeu. Ética e filosofia política: Hegel e o formalismo kantiano. 2. ed. Porto Alegre: Edipucrs, 2009. p. 51.

20 BARROSO, Luís Roberto. A dignidade da pessoa humana no direito contemporâneo: a construção de um conceito à luz da jurisprudência. Belo Horizonte: Fórum, 2013. p. 72.

21 SARLET, Ingo. Dignidade da pessoa humana e direitos fundamentais na Constituição Federal de 1988. 9. ed. Porto Alegre: Livraria do Advogado, 2012. p. 42.

22 NOVAES, Jorge Reis. Direitos fundamentais e justiça constitucional: em um Estado de direito democrático. Coimbra: Coimbra, 2010. p. 44.

23 UNESCO. Declaração universal dos direitos humanos. Brasília, DF: UNESCO, 1998. Disponível em: <http://unesdoc.unesco.org/images/0013/001394/139423por.pdf>. Acesso em: 02 out. 2015. 
humanos consagraram o princípio da dignidade da pessoa humana, com importante destaque para a Carta de Direitos Fundamentais da União Europeia, assinada em Nice, em dezembro de 2000, a qual dispõe, no seu art. 1ㅇ․ “[...] A dignidade do ser humano é inviolável". ${ }^{24}$

Máxima que justifica em parte o princípio, ainda que merecedora de críticas pela evidente simplificação com que é exposta aqui, e não inclua os particulares como violadores da dignidade da pessoa humana, está expressa nas palavras de Dworkin:

[...] o governo deve tratar aqueles a quem governa com consideração, isto é, como seres humanos capazes de sofrimento e de frustração, e com respeito, isto é, como seres humanos capazes de formular concepções inteligentes sobre o modo como suas vidas devem ser vividas, e agir de acordo com elas. O governo deve não somente tratar as pessoas com consideração e respeito, mas com igual consideração e igual respeito. Não deve distribuir bens ou oportunidades de maneira desigual, com base no pressuposto de que alguns cidadãos têm direitos a mais, por serem merecedores de maior consideração. ${ }^{25}$

Dignidade não implica apenas que a pessoa não pode ser reduzida à condição de mero objeto da ação própria e de terceiros, mas também "o fato de que a dignidade gera direitos fundamentais (negativos) contra atos que a violem ou a exponham a graves ameaças, sejam tais atos oriundos do Estado, sejam provenientes de atores privados". Fundamental é assegurar ao ser humano, "por meio de medidas positivas (prestações), o devido respeito" ${ }^{26}$

A dignidade da pessoa humana deve ser respeitada nos âmbitos estatal e comunitário e necessita ser garantida por um complexo de direitos e deveres que são incompatíveis com o tratamento cruel, desumano e degradante perpetuado por parte do Estado e de particulares às pessoas. Deve ser garantido um mínimo social consubstanciado no direito a prestações estatais enquanto direitos fundamentais sociais.

24 CARTA dos direitos fundamentais da União Europeia. Jornal Oficial das Comunidades Europeias, [S.I.], 18 dez. 2000. Disponível em: <http://www.europarl.europa.eu/charter/pdf/text_pt.pdf>. Acesso em: 01 maio 2016.

25 DWORKIN, Ronald. Taking rights seriously. Cambridge: Harvard University Press, 1977. p. 419.

26 SARLET, Ingo. Comentários ao art. 1, inc. III, da CF/88. In: CANOTILHO, J. J. Gomes et al. (Coord.). Comentários à Constituição do Brasil. São Paulo: Saraiva: Almedina, 2013. p. 121. 


\section{Dignidade da pessoa humana na jurisprudência estrangeira}

A dignidade da pessoa humana vem sendo reconhecida por diversas decisões de tribunais estrangeiros, as quais fixam a sua limitação e seus parâmetros, densificando-a, enquanto princípio, no enfrentamento dos casos em concreto. A construção e a modulação de um conceito jurídico do princípio da dignidade da pessoa humana são realizadas, para além dos diplomas legais, pela norma que emana da aplicação desse princípio pelas Cortes.

Na Alemanha, o Tribunal Constitucional Federal decidiu, no ano de 1994, pela proibição da negação do Holocausto, com citação expressa ao princípio da dignidade da pessoa humana. ${ }^{27}$ Já no ano de 2006, o Tribunal entendeu pela proibição do abate de aeronaves sequestradas por terroristas que - ao estilo onze de setembro, no atentado contra as torres gêmeas do World Trade Center, em Nova York - poderiam desviá-las contra alvos predeterminados para ceifar vidas humanas. Mais precisamente, o Tribunal entendeu pela inconstitucionalidade de legislação que concedia ao Ministro da Defesa poderes para determinar o abate de aviões civis quando fosse possível a sua utilização para destruir vidas humanas. ${ }^{28}$

$\mathrm{Na}$ França, embora exista uma tradição cultural marcada pelo lema liberdade, igualdade e fraternidade, houve duas polêmicas decisões do Conselho Constitucional ao apreciar o princípio da dignidade da pessoa humana. O Conselho Constitucional, em 2010, entendeu como constitucional a lei que tornou ilegal o uso, em público, de véu que cobrisse integralmente o rosto das mulheres, o que, nesse contexto, por consequência, acabou proibindo a utilização da burca pelas muçulmanas. ${ }^{29} \mathrm{~A}$ decisão causou forte resistência na comunidade islâmica francesa e protestos de muçulmanos em todo o mundo, em especial no Oriente Médio. É de se entender como justificável a referida decisão, em que pesem os acalorados debates que a envolveram, em virtude do risco de atentados terroristas tão em voga nos dias atuais, em especial na França, como demonstrado nos sangrentos anos de 2015 e 2016 . Ocorreu uma evidente intervenção no direito de liberdade religiosa da mulher muçulmana e na sua dignidade enquanto ser humano. Após uma ponderação de valores e princípios, o Conselho decidiu

DEUTSCHLAND. Bundesverfassungsgericht. 90 BerfGE 241 [1994].

28 DEUTSCHLAND. Bundesverfassungsgericht. BerfG, 1 BvR 357/05. Ver: DEUTSCHLAND. Bundesverfassungsgericht. Karlsruhe, 2015. Disponivel em: <http://www.bundesverfassungsge richt.de/ en/press/bvg06-011en.html>. Acesso em: 11 out. 2015.

29 PARIS. Conseil Constitutionnel. Décision no 2010-613 DC du 7 octobre 2010. Disponivel em: <http:// www. conseil-constitutionnel.fr/decision/2010/2010-613-dc/decision-n-2010-613-dc-du-07-octobre-2010. 49711.html>. Acesso em: 01 jul. 2015. 
que deveria preponderar a preservação e a proteção da dignidade e do direito fundamental à vida das pessoas possíveis vítimas de atos terroristas.

Não andou bem o Conselho Constitucional em outro caso, ao decidir como constitucional legislação que proibia o casamento entre pessoas do mesmo sexo. ${ }^{30}$ A discriminação contra o casamento gay, ainda que seja reconhecida a polêmica que o envolve, não possui mais respaldo em uma sociedade que respeita a dignidade da pessoa humana e os direitos fundamentais.

Cortes francesas já demonstraram maior sensibilidade no tocante ao princípio da dignidade da pessoa humana. Foi assim na Decisão do Conselho de Estado, em 1995, que acolheu o recurso da Comune de Morsang-Sur-Orge e entendeu como legítimo o provimento do poder público municipal no sentido de proibir, por motivo de ordem pública, o espetáculo em uma casa noturna chamado "lançamento de anões". Para o Conselho de Estado, pouco importa se o anão, principal ator do espetáculo, consentiu ou se ganhava a vida com a referida atividade. Acima deste aspecto - direito de escolha do anão em participar do show -, está a dignidade da pessoa humana, que é um dos elementos essenciais para a ordem pública. ${ }^{31}$ Referida decisão foi reconhecida como correta no âmbito doutrinário. ${ }^{32}$

Nos Estados Unidos, não há referência expressa à dignidade da pessoa humana no texto da Constituição. Apesar disso, desde meados dos anos 1940, esse conceito tem adquirido influência na jurisdição constitucional americana. ${ }^{33}$ Esclarece Barroso que a primeira aparição da expressão dignidade humana, em um voto majoritário, deu-se no caso Rochin v. Califórnia. ${ }^{34}$ No referido leading case, a Suprema Corte debateu a possibilidade de a polícia utilizar-se de expedientes médicos e da força para fazer um suspeito vomitar cápsulas que havia engolido para a ocultação de provas contra si mesmo. Esse expediente, é de se salientar, foi entendido como legal e motivou a condenação de Rochin no primeiro grau. Os Justices entenderam, ao apreciar o recurso da decisão, que a condenação se deu com métodos que violaram o devido processo legal e que o uso de tal força foi

30 CONSEIL constitutionnel dit non au marriage homossexual. Le Soir, France, Jan. 28, 2011. 2011. Disponível em: <http://www.lesoir.be/actualite/ france/2011-01-28/leconseil-constitutionnel-dit-non-aumariage-homesexuel-818228.php>. Acesso em: 01 jul. 2015.

31 FRANCE. Conseil d'Etat, n 136727, 27 outubre 1995, Commune de Morsang-Sur-Orge.

32 Ridola, ao comentar o caso, refere-se a uma noção de recuperação da ordem pública que tem encontrado resistência na cultura jurídica francesa, mas que tem sido bem acolhida pela jurisprudência do Conselho de Estado (Conseil d'État), desde o final dos anos 1950, por via da qual a moralidade deve ser reconhecida como elemento componente do conceito de ordem pública, algo como um "mínimo ético comum" compartilhado por toda a sociedade (RIDOLA, Paolo. A dignidade humana e o "princípio liberdade" na cultura constitucional européia. Porto Alegre: Livraria do Advogado, 2014. p. 33).

33 BARROSO, Luis Roberto. A dignidade da pessoa humana no direito contemporâneo: a construção de um conceito à luz da jurisprudência. Belo Horizonte: Fórum, 2013. p. 40.

34 BARROSO, Luis Roberto. A dignidade da pessoa humana no direito contemporâneo: a construção de um conceito à luz da jurisprudência. Belo Horizonte: Fórum, 2013. 
brutal e excessivo para a dignidade da pessoa humana na obtenção de provas contra um suspeito de crime. ${ }^{35}$

A dignidade da pessoa humana, igualmente, foi um dos argumentos importantes invocados no julgamento do caso Brown v. Board of Education. ${ }^{36}$ Esse foi um dos mais importantes leading cases julgados pela Suprema Corte americana, envolvendo a aplicação do princípio da dignidade da pessoa humana a fim de impedir a segregação entre negros e brancos nas escolas públicas. Mesmo após a decisão do caso Brown, é importante que se faça o registro: vários Estados do sul dos Estados Unidos continuaram a desafiar a lei até a aprovação do Civil Rights Act of $1964,{ }^{37}$ que foi um marco no plano legislativo em defesa dos direitos civis. Referido diploma legal prevê, de modo expresso, a ilegalidade de qualquer discriminação baseada na raça, na cor, na religião, no sexo ou na origem nacional.

Como bem referido por Ackerman, na recente obra que completa sua trilogia, We the People, com o Civil Rights Act of 1964, os americanos começaram a resolver uma década de debates provocados por Brown para dar a ele um apoio sustentado por uma legislação de referência que repetidamente reafirmou os princípios de Warren. E, nesse exemplo-chave, o esforço para redefinir esse cânone constitucional e incluir estatutos de referência teve a paradoxal consequência de exigir que os operadores do direito levem a Suprema Corte mais a sério e tratem o caso Brown pelo que ele foi: a maior decisão judicial do século $\mathrm{XX}^{38}$ no reconhecimento da dignidade da pessoa humana nos Estados Unidos.

Digno de nota, também, o caso Lawrence v. Texas. ${ }^{39}$ Nos Estados Unidos, o cenário de discriminação contra a comunidade gay começou a mudar quando John Geddes Lawrence, um homem de 60 anos, e seu parceiro sexual, Garner, de 36, foram flagrados, mediante denúncia anônima desvinculada ao fato, praticando sexo no apartamento de Lawrence. Ambos foram presos e acusados de violação

35 UNITED STATES. Supreme Court. Rochin v. California, 342 U.S. 165, 174 (1952). De modo mais aprofundado, ver Rochin v. California em: GUNTHER, Gerald; SULLIVAN, Kathleen. Constitutional law. 13th ed. New York: The Fondation Press, 1997. p. 440 e ss.

36 UNITED STATES. Supreme Court. Brown v. Board of Education, 347 U.S. 438 (1954). Ver sobre os casos Brown v. Board Education of Topeka (Brown I) e Brown v. Board Education of Topeka (Brown II) em: STONE, Geoffrey et al. Constitutional law. keyed to courses using. 6th ed. New York: Wolters Kluwer, 2010. p. 54-56. De um modo mais abrangente e aprofundado, ver sobre os referidos leading cases em: GUNTHER, Gerald; SULLIVAN, Kathleen. Constitutional law. 13th ed. New York: The Fondation Press, 1997. p. 673681.

37 UNITED STATES Congress. Civil Rights Act of 1964. Disponivel em: <https://www.loc.gov/ exhibits/civilrights-act/civil-rights-act-of-1964.html>. Acesso em: 10 nov. 2015.

38 ACKERMAN, Bruce. We the people: the civil rights revolution. Cambridge: The Belknap Press of Harvard University, 2014. 3 v. p. 317.

39 UNITED STATES. Supreme Court. Lawrence v. Texas 539 U.S.558 [2003]. Ver também sobre o caso Lawrence v. Texas: STONE, Geoffrey et al. Constitutional law. keyed to courses using. 6th ed. New York: Wolters Kluwer, 2010. p. 93. 
à Lei de Sodomia do Texas. A lei proibia as práticas de sexo anal e oral entre pessoas do mesmo sexo. Cada um dos acusados pagou US $\$ 125$ dólares de fiança para responder ao processo em liberdade. Ambos apresentaram defesa em juízo, mas restaram condenados por praticarem "sexo desviante". A Corte de Apelação do Texas, após interposição de recurso pelos condenados, decidiu, por 7 a 2, que a Lei de Sodomia era constitucional.

A Suprema Corte dos Estados Unidos, no ano de 2002, depois de novo recurso, apreciou o caso em caráter definitivo e anulou a lei que criminalizava a sodomia no Estado do Texas. A Corte alterou, assim, a jurisprudência anterior que havia ratificado a Lei de Sodomia do Estado da Geórgia, no leading case Bowers Vs Hardwick, ${ }^{40}$ no ano de 1986, reconhecendo a autonomia dos Estados para legislar nesse tipo de matéria. A nova decisão se deu porque a Lei de Sodomia do Texas violava a 14를 Emenda da Constituição americana quando previa que o sexo praticado entre pessoas do mesmo sexo era ilegal e, também, por desrespeitar a intimidade e a prática sexual consensual. Constou no voto do Justice Kennedy (posição majoritária) a expressão dignidade humana em várias passagens. ${ }^{41}$

$\mathrm{O}$ direito fundamental ao desenvolvimento sustentável na era das mudanças climáticas, aqui proposto, é norteado pelo princípio da dignidade da pessoa humana.

\section{Dignidade da pessoa humana sob a égide da Constituição de 1988}

A Constituição Federal de 1988, após longo período de ditadura militar, previu entre os seus princípios fundamentais e como um dos seus fundamentos a dignidade da pessoa humana (art. 1ํ, inc. III). Tal previsão repetiu-se: no art. 170, caput, quando deixou claro que "a ordem econômica tem por finalidade assegurar a todos uma existência digna"; no art. 226, §7ํㅜ , que diz "na ordem social, com o planejamento familiar fundado nos princípios da dignidade da pessoa humana e da paternidade responsável"; e, no mesmo sentido, no art. 227, caput, quando assegura "à criança e ao adolescente o direito à dignidade". Está disposto no art. 230 que "a família, a sociedade e o Estado têm o dever de amparar as pessoas idosas, assegurando sua participação na comunidade, defendendo sua dignidade e bem-estar e garantindo-Ihes o direito à vida". O Ato das Disposições

40 Sobre o caso Bowers v. Hardwick, ver: GUNTHER, Gerald; SULLIVAN, Kathleen. Constitutional law. 13th ed. New York: The Fondation Press, 1997. p. 543, 593, 746.

41 WEDY, Gabriel. As uniões homoafetivas e o preconceito. O Sul, Porto Alegre, 18 ago. 2013. Caderno de Colunistas, p. 3. 
Constitucionais Transitórias (ADCT), no seu art. 79, dispõe sobre o Fundo de Combate e Erradicação da Pobreza, cuja finalidade é "viabilizar a todos os brasileiros acesso a níveis dignos de subsistência". Com esse mesmo espírito de respeito à dignidade da pessoa humana, o Constituinte originário inseriu no texto da Carta Política, no seu art. 5으, inc. III, "a proibição da tortura e ao tratamento desumano e degradante" e, no inc. XLVII, "a vedação, entre outras, de penas cruéis".

Essa nítida tendência de inserção expressa no texto constitucional do princípio da dignidade da pessoa humana, após períodos autoritários, pode ser verificada de modo idêntico nas constituições da Alemanha (art. 1ํㅡ, inc. I), Espanha (preâmbulo e art. 10.1), Portugal (art. 1ํ) e Itália (art. 3ํ). Não há dúvida de que o exemplo dessas constituições, que consagraram o princípio da dignidade da pessoa humana após passarem por ditaduras lideradas, respectivamente, por Hitler, Franco, Salazar e Mussolini, serviu de exemplo e inspiração para o Poder Constituinte de 1988, que vivia os ares da redemocratização após mais de vinte anos de recorrentes episódios de criminosas violações dos direitos humanos protagonizados por ambos os lados da refrega no episódio do Golpe Militar. Impossível negar, contudo, que existem mais registros de vítimas de violações dos direitos humanos no lado que foi apeado do Poder em 1964.

Nesse sentido, o Estado brasileiro existe para e em função da pessoa humana (com dignidade). Não é a pessoa humana que existe como mero instrumento e objeto do poder estatal, como nos regimes totalitários, notadamente fascistas, nazistas e comunistas (tal qual o implantado, também, na extinta União Soviética e nos países da extinta cortina de ferro).

O valor e princípio fundamental da dignidade da pessoa humana devem servir de norte para o intérprete da Constituição como balizador, otimizador e limitador para a aplicação proporcional dos direitos fundamentais previstos, explícita e implicitamente, na nossa Magna Carta. É função do princípio da dignidade da pessoa humana atribuir força normativa à Constituição e conferir eficácia máxima aos direitos fundamentais negativos e prestacionais. Portanto, correndo o risco da redundância, o princípio da dignidade da pessoa humana não é um direito fundamental. O princípio tem um caráter multidimensional. As suas dimensões são “ontológica (não necessariamente biológica), histórico-cultural e sua dupla dimensão (ou função) negativa e prestacional, ao que se poderia ainda agregar a igualmente dupla dimensão objetiva e subjetiva da dignidade". ${ }^{42}$

42 SARLET, Ingo. Dignidade da pessoa humana e direitos fundamentais na Constituição Federal de 1988. 9. ed. Porto Alegre: Livraria do Advogado, 2012. p. 72. 
O princípio da dignidade da pessoa humana, em todas as suas dimensões, está no cume de nosso sistema jurídico, constitucional e infraconstitucional, e, além de possuir indiscutível eficácia e valor axiológico máximo, também é um objetivo a ser seguido pelo Estado e por particulares. Correto afirmar que o princípio da dignidade da pessoa humana atua como um mandado de otimização que vincula particulares e o Estado no âmbito das suas três funções: judicial, executiva e legislativa. $\mathrm{Na}$ sua dimensão negativa, protege e defende o cidadão contra intervenções indevidas do Estado e de particulares violadoras de direitos individuais fundamentais. São exemplos de sua função positiva os direitos sociais fundamentais à saúde, à educação e à moradia.

Embora nem todos os direitos fundamentais tenham um fundamento direto na dignidade da pessoa humana, segue sendo correta a afirmação de que, em sua maioria, os direitos fundamentais constituem, em maior ou menor medida, explicitações ou, como preferem outros, densificações do princípio da dignidade da pessoa humana. Em outras palavras, em cada direito fundamental, faz-se presente um conteúdo ou, pelo menos, alguma projeção da dignidade humana. ${ }^{43}$

Não há dúvida de que a violação de um direito fundamental pode violar, ao mesmo tempo, o princípio da dignidade da pessoa humana. Essa, aliás, é a regra na maioria dos casos; todavia, pode, em sentido oposto, servir o princípio como limitador, dentro de um juízo de proporcionalidade, de determinado direito fundamental. É o caso, por exemplo, de o princípio da dignidade da pessoa humana ser utilizado na construção de um discurso jurídico e de uma fundamentação limitadora do direito de propriedade.

Pode-se avançar no tema, ainda, no sentido da afirmação de que o princípio da dignidade da pessoa humana pode limitar a análise do custo-benefício ${ }^{44}$ de medidas adotadas pelo Estado, procedimento aplicado no direito norte-americano

${ }^{33}$ SARLET, Ingo. Comentários ao art. 1, inc. III, da CF/88. In: CANOTILHO, J. J. Gomes et al. (Coord.). Comentários à constituição do Brasil. São Paulo: Saraiva: Almedina, 2013. p. 127.

44 Sunstein defende a utilização do procedimento da análise do custo-benefício no caso da aplicação do DDT (diclorodifeniltricloroetano) na agricultura dos países africanos. Também entende como válido o procedimento para avaliar a regulação do arsênico na água de beber nos Estados Unidos, sem analisar, com maior profundidade, o risco de violação ao princípio da dignidade da pessoa humana e a outros direitos fundamentais, em especial o direito à vida, à saúde e à tutela do meio ambiente. Para verificar a posição de Sunstein em defesa da análise do custo-benefício dessas medidas, ver: SUNSTEIN, Cass. Laws of fear: beyond the precautionary principle. New York: Cambridge Press, 2005; SUNSTEIN, Cass. The arithmetic of arsenic, 90. Georgetown Law Review, Washington, n. 2255, p. 2261-2263, 2002; SUNSTEIN, Cass. Worst-case scenarios. Cambridge: Harvard University Press, 2007. Para a apreciação crítica da posição externada pelo Professor da Harvard Law School e da defesa da aplicação da análise do custo-benefício, em uma versão mais cautelosa, observado o princípio da proporcionalidade nos seus dois vetores, vedação do excesso e da insuficiência, ver: WEDY, Gabriel. O princípio constitucional da precaução como instrumento de tutela do meio ambiente e da saúde pública. Belo Horizonte: Interesse Público, 2009. 
como reminiscência do utilitarismo ${ }^{45}$ quando adotado em sua versão forte e radical. É intuitivo que, se o princípio da dignidade da pessoa humana pode o mais, ou seja, limitar e restringir o núcleo essencial de direitos fundamentais em um juízo de proporcionalidade, pode, também, limitar políticas públicas calcadas na análise do custo-benefício de medidas que violam bens, valores e direitos que o direito não pode comprar. ${ }^{46}$

É de se observar que Sandel refuta como aceitável uma sociedade em que todos os valores estão à venda. Refere que existem certos bens morais e cívicos que os mercados não respeitam e o dinheiro não pode comprar. ${ }^{47} \mathrm{O}$ princípio da dignidade da pessoa humana é um limitador moral e jurídico dos mercados. A observância do princípio é essencial para que as pessoas possam conviver de modo comunitário, respeitando as suas diferenças, mas sem serem excluídas da sociedade e afastadas de bens essenciais que proporcionam uma vida digna e boa.

\section{Dignidade da pessoa humana segundo o STF}

O Supremo Tribunal Federal fez referência à dignidade da pessoa humana em diversos julgados posteriormente à promulgação da Constituição Cidadã de 1988. A importância da jurisprudência no alcance e na realização normativa do princípio da dignidade da pessoa humana está no fato de que "é no constante manejo da riqueza de aportes oferecidos pela casuística que se torna possível uma aproximação do que constitui dignidade da pessoa humana em cada caso concreto". 48

Nos âmbitos do processo penal e do direito penal, a jurisprudência do Supremo Tribunal Federal tem debatido e reconhecido, com maior intensidade, o princípio da dignidade da pessoa humana. Como noticiado por Barroso, a dignidade da pessoa humana foi mencionada, em decisões do STF, assegurando aos sujeitos passivos em procedimentos criminais o direito: a) à não autoincriminação; ${ }^{49}$

45 Sobre o utilitarismo, ver: MILL, John Stuart. On liberty and other writings. London: Cambridge Univesity Press, 2012. E, também: MILL, John Stuart; BENTHAM, Jeremy. Utilitarianism and other essays. London: Penguin, 2004.

46 SANDEL, Michael. What's money can't buy? The moral limits of market. New York: Farrar, Straus and Giroux, 2012.

47 SANDEL, Michael. What's money can't buy? The moral limits of market. New York: Farrar, Straus and Giroux, 2012. p. 203.

48 SARLET, Ingo. Comentários ao art. 1, inc. III, da CF/88. In: CANOTILHO, J. J. Gomes et al. (Coord.). Comentários à Constituição do Brasil. São Paulo: Saraiva: Almedina, 2013. p. 128.

49 BRASIL. Supremo Tribunal Federal. HC n. 79.812/SP. Relator: Ministro Celso de Mello. Diário da Justiça da União, Brasília, DF, 16 fev. 2001. Disponível em: <http://www.stf.jus.br/portal/inteiroTeor/ pesquisarlnteiroTeor.asp>. Acesso em: 02 nov. 2014. 
b) à presunção de inocência; ${ }^{50} \mathrm{c}$ ) à ampla defesa; ${ }^{51} \mathrm{~d}$ ) contra o excesso de prazo em prisão preventiva; ${ }^{52}$ e) ao livramento condicional; ${ }^{53}$ f) às saídas temporárias do preso; ${ }^{54} \mathrm{~g}$ ) à não utilização injustificada de algemas; ${ }^{55} \mathrm{~h}$ ) à aplicação do princípio da insignificância; ${ }^{56}$ e i) ao cumprimento de pena em prisão domiciliar. ${ }^{57}$ Cita 0 jurista, ainda, que "a ideia kantiana do fim-em-si foi utilizada em acórdão em que se discutiu a competência para julgamento de crime de redução de pessoas à condição análoga à de escravo". ${ }^{58}$

Existem precedentes importantes no STF que mencionam a dignidade da pessoa humana no que concerne à proibição da tortura e do tratamento desumano, degradante e crue ${ }^{59}$ e ao tratamento diferenciado em relação aos portadores de deficiência. ${ }^{60} 0$ princípio da dignidade da pessoa humana, dentro de uma perspectiva de ativismo judicial, serviu como embasamento para garantir o direito à educação,

50 BRASIL. Supremo Tribunal Federal. HC n. 93.782/RS. Relator: Ministro Ricardo Lewandowski. Diário da Justiça da União, Brasília, DF, 17 out. 2008. Disponível em: <http://www.stf.jus.br/ portal/inteiroTeor/ pesquisarlnteiroTeor.asp>. Acesso em: 02 nov. 2014.

51 BRASIL. Supremo Tribunal Federal. HC n. 85.327/SP. Relator: Ministro Gilmar Mendes. Diário da Justiça da União, Brasília, DF, 20 out. 2006. Disponível em: <http://www.stf.jus.br/portal/inteiroTeor/ pesquisarlnteiroTeor.asp>. Acesso em: 02 nov. 2014.

52 BRASIL. Supremo Tribunal Federal. HC n. 98.579/SP. Relator p/ acórdão: Ministro Celso de Mello. Diário da Justiça da União, Brasília, DF, 30 abr. 2010. Disponível em: <http://www.stf.jus.br/portal/ inteiroTeor/ pesquisarlnteiroTeor.asp>. Acesso em: 02 nov. 2014.

53 BRASIL. Supremo Tribunal Federal. HC n. 99.652/RS. Relator: Ministro Carlos Britto. Diário da Justiça da União, Brasília, DF, 04 dez. 2009. Disponível em: <http://www.stf.jus.br/portal/ inteiroTeor/ pesquisarlnteiroTeor.asp>. Acesso em: 02 nov. 2014.

54 BRASIL. Supremo Tribunal Federal. HC n. 98.067/RS. Relator: Ministro Marco Aurélio. Diário da Justiça da União, Brasília, DF, 20 maio 2010. Disponível em: <http://www.stf.jus.br/portal/ inteiroTeor/ pesquisarlnteiroTeor.asp>. Acesso em: 02 nov. 2014.

55 BRASIL. Supremo Tribunal Federal. HC n. 91952/SP. Relator: Ministro Marco Aurélio. Diário da Justiça da União, Brasília, DF, 19 dez. 2008. Disponível em: <http://www.stf.jus.br/portal/ inteiroTeor/ pesquisarlnteiroTeor.asp>. Acesso em: 02 nov. 2014.

56 BRASIL. Supremo Tribunal Federal. HC n. 90.125/RS. Relator: Ministro Eros Grau. Diário da Justiça da Uniao, Brasília, DF, 05 set. 2008. Disponível em: <http://www. stf.jus.br/portal/processo/ver ProcessoAndamento.asp?incidente=2449895>. Acesso em: 02 nov. 2014.

57 BRASIL. Supremo Tribunal Federal. HC n. 83.358/SP. Relator: Ministro Carlos Britto. Diário da Justiça da União, Brasília, DF, 04 jun. 2004. Disponível em: <http://www.stf.jus.br/portal/inteiroTeor/ pesquisarlnteiroTeor.asp>. Acesso em: 02 nov. 2014.

58 Luis Roberto Barroso faz referência precisamente ao seguinte leading case: BRASIL. Supremo Tribunal Federal. RE n. 398.041/PA. Relator: Ministro Joaquim Barbosa. Diário da Justiça da União, Brasília, DF, 19 dez. 2008. Disponível em: <http://www.stf.jus.br/portal/inteiroTeor/pesquisar InteiroTeor.asp>. Acesso em: 02 nov. 2014. Ver: BARROSO, Luís Roberto. A dignidade da pessoa humana no direito contemporâneo: a construção de um conceito à luz da jurisprudência. Belo Horizonte: Fórum, 2013. p. 116.

59 BRASIL. Supremo Tribunal Federal. HC n. 70.389. Relator: Ministro Celso de Mello. Diário da Justiça da União, Brasília, DF, 10 ago. 2001. Disponível em: <http://www.stf.jus.br/portal/inteiroTeor/ pesquisarlnteiroTeor.asp>. Acesso em: 02 nov. 2014.

60 BRASIL. Supremo Tribunal Federal. Ação direta de inconstitucionalidade n. 2649/DF. Relatora: Ministra Carmem Lúcia. Diário da Justiça da União, Brasília, DF, 17 out. 2008. Disponível em: <http://stf.jusbrasil. com.br/jurisprudencia/2919542/acao-direta-de-inconstitucionalidade-adi-2649-df>. Acesso em: 02 nov. 2014. 
para fins de matrícula de criança na pré-escola ${ }^{61}$ e na garantia do direito à saúde, quando envolvidos procedimentos cirúrgicos e medicamentos não fornecidos pelo SUS. ${ }^{62}$

A dignidade da pessoa humana igualmente é invocada pelo Judiciário, com alguma frequência, nas ponderações de valores que envolvem o direito à vida e à saúde dos demandantes. Entes estatais, em demandas do estilo, alegam invariavelmente, na sua defesa, o direito à saúde das pessoas que estão na fila do SUS e não podem contratar advogados privados, além da finitude dos recursos estatais, ancorada no princípio da reserva do possível. ${ }^{63}$

Barroso apresenta crítica à aplicação banalizada do princípio pelo STF, ${ }^{64}$ citando como exemplo o caso da declaração de inconstitucionalidade da Lei no 2.895/98 do Estado do Rio de Janeiro, que autorizava a exposição e a competição de aves combatentes, ${ }^{65}$ uma prática tradicional e cruel popularmente conhecida como "rinha de galos". A decisão, do ano de 2011, foi no sentido de que a lei impugnada autorizou prática considerada como crime pela legislação ambiental nacional e expressamente proibida pelo texto constitucional, que é claro ao vedar a submissão de animais a atos de crueldade, além de prever o direito fundamental à preservação da integridade do meio ambiente (art. 225, caput, §1으, VII). Entretanto, o Ministro Peluso, acompanhado por dois outros ministros, referiu no seu voto que a lei debatida violava o princípio da dignidade da pessoa humana, uma vez que a legislação estadual estimularia prática de atos degradantes, por sua irracionalidade, à figura humana. Esses argumentos afiguram-se um "uso alargado em demasia do princípio". ${ }^{66}$

61 BRASIL. Supremo Tribunal Federal. Recurso extraordinário com agravo n. 639.337/SP. Relator: Ministro Celso de Mello. Diário da Justiça da União, Brasília, DF, 14 set. 2011. Disponível em: <http://stf.jusbrasil. com.br/jurisprudencia/22932599/recurso-extraordinario-com-agravo-are-639337-sp-stf>. Acesso em: 02 nov. 2014.

62 BRASIL. Supremo Tribunal Federal. Suspensão de tutela antecipada n. 316/SC. Relator: Ministro Gilmar Mendes. Diário da Justiça da União, Brasília, DF, 26 abr. 2010. Disponível em: <http:// stf.jusbrasil.com. br/jurisprudencia/19133178/suspensao-de-tutela-antecipada-sta-316-sc-stf>. Acesso em: 02 nov. 2014.

63 Ver: BARROSO, Luís Roberto. Da falta de efetividade à judicialização excessiva: direito à saúde, fornecimento gratuito de medicamentos e parâmetros para a atuação judicial. Interesse Público - IP, Belo Horizonte, ano 9, n. 46, p. 01-37, 2007.

64 BARROSO, Luís Roberto. A dignidade da pessoa humana no direito contemporâneo: a construção de um conceito à luz da jurisprudência. Belo Horizonte: Fórum, 2013. p. 117.

65 BRASIL. Supremo Tribunal Federal. Ação Direta de Inconstitucionalidade n. 1856/RJ. Relator: Ministro Carlos Velloso. Diário da Justiça da União, Brasília, DF, 03 set. 1998. Disponível em: <http://stf.jusbrasil. com.br/jurisprudencia/20626753/acao-direta-de-inconstitucionalidade-adi-1856-rj-stf>. Acesso em: 02 nov. 2014.

66 Afirma Barroso que "[...] poderia ter sido suscitado, isso sim, o reconhecimento de dignidade dos animais. Uma dignidade que, naturalmente, não é humana nem deve ser aferida por seu reflexo sobre as pessoas humanas, mas pelo fato de os animais, como seres vivos, terem uma dignidade intrínseca e própria" (BARROSO, Luís Roberto. A dignidade da pessoa humana no direito contemporâneo: a construção de um conceito à luz da jurisprudência. Belo Horizonte: Fórum, 2013. p. 118). 
Sempre haverá como sustentar a dignidade da própria vida de um modo geral, ainda mais numa época em que o reconhecimento da proteção do meio ambiente como valor fundamental indica que não mais está em causa apenas a vida humana, mas a preservação de todos os recursos naturais, incluindo todas as formas de vida existentes no planeta. ${ }^{67}$ É o entendimento exposto, também, pela melhor doutrina em sede de direito ambiental internacional, ou seja, de que todos os seres são interdependentes e cada forma de vida tem valor de modo independente de sua utilidade para os seres humanos. ${ }^{68}$

Aprofundando o tema, o STF, ao julgar improcedente a ADI no $3.510,69$ causou polêmica ao declarar constitucional a pesquisa com células-tronco. Desse modo, a integralidade do art. 5으 da Lei o 11.105/2005 (Lei de Biossegurança) foi considerada compativel com o texto da Constituição. Na decisão, constou expressamente que não existe violação do direito à vida nas pesquisas com células-tronco embrionárias para fins terapêuticos e, tampouco, aborto. Foram reconhecidas normas constitucionais conformadoras do direito fundamental a uma vida digna, notadamente o direito à saúde e ao planejamento familiar.

A pesquisa científica com células-tronco embrionárias, segundo o STF, objetiva:

[...] a cura de patologias e traumatismos que severamente limitam, atormentam, infelicitam, desesperam e não raras vezes degradam a vida de expressivo contingente populacional (ilustrativamente, atrofias espinhais progressivas, distrofias musculares, a esclerose múltipla e a lateral amiotrófica, as neuropatias e as doenças do neurônio motor). ${ }^{70}$

No voto do Ministro Celso de Mello, restou consignado que:

[...] não houve ofensas ao direito à vida e à dignidade da pessoa humana, pois a pesquisa com células-tronco embrionárias significa

67 SARLET, Ingo. Dignidade da pessoa humana e direitos fundamentais na Constituição Federal de 1988. 9. ed. Porto Alegre: Livraria do Advogado, 2012. p. 43.

68 Bosselmann faz referência ao art. 1ํ da Carta da Terra, que prevê o respeito à Terra e à vida em toda a sua diversidade (BOSSELMANN, Klaus. The principle of sustainability: transforming law and governance. Farnham: Ashgate, 2008. p. 75).

69 BRASIL. Supremo Tribunal Federal. ADI n. 3510. Relator: Ministro Carlos Britto. Diário da Justiça da União, Brasília, DF, 29 maio 2008. Disponível em: <http://www.stf.jus.br/portal/inteiroTeor/ pesquisarlnteiroTeor.asp>. Acesso em: 02 nov. 2014.

70 BRASIL. Supremo Tribunal Federal. ADI n. 3510. Relator: Ministro Carlos Britto. Diário da Justiça da União, Brasília, DF, 29 maio 2008. Disponível em: <http://www.stf.jus.br/portal/inteiroTeor/ pesquisarlnteiroTeor.asp>. Acesso em: 02 nov. 2014. 
a celebração solidária da vida e alento aos que se acham à margem do exercício concreto e inalienável dos direitos à felicidade e do viver com dignidade. ${ }^{71}$

Os ministros entenderam que a opção do casal por um processo in vitro de fecundação artificial de óvulos, também prevista na lei impugnada, "é implícito direito de idêntica matriz constitucional, sem acarretar para esse casal o dever jurídico do aproveitamento reprodutivo de todos os embriões eventualmente formados e que se revelem geneticamente viáveis". ${ }^{72}$ Consta do acórdão outra referência ao princípio da dignidade da pessoa humana na linha de que tal princípio:

[...] opera por modo binário, o que propicia a base constitucional para um casal de adultos recorrer a técnicas de reprodução assistida que incluam a fertilização artificial ou in vitro. De uma parte, para aquinhoar o casal com o direito público subjetivo à 'liberdade' (preâmbulo da Constituição e seu art. 5으), aqui entendida como autonomia de vontade. De outra banda, para contemplar os porvindouros componentes da unidade familiar, se por eles optar o casal, com planejadas condições de bem-estar e assistência físico-afetiva (art. 226 da CF). ${ }^{73}$

Assim, o planejamento familiar, "fruto da livre decisão do casal", é "fundado nos princípios da dignidade da pessoa humana e da paternidade responsável (art.

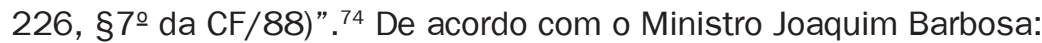

[...] igualmente, a decisão por uma descendência ou filiação exprime um tipo de autonomia de vontade individual que a própria Constituição rotula como direito ao planejamento familiar, fundamentado este

71 BRASIL. Supremo Tribunal Federal. ADI n. 3510. Relator: Ministro Carlos Britto. Diário da Justiça da União, Brasília, DF, 29 maio 2008. Disponível em: <http://www.stf.jus.br/portal/inteiroTeor/ pesquisarlnteiroTeor.asp>. Acesso em: 02 nov. 2014.

72 BRASIL. Supremo Tribunal Federal. ADI n. 3510. Relator: Ministro Carlos Britto. Diário da Justiça da União, Brasília, DF, 29 maio 2008. Disponível em: <http://www.stf.jus.br/portal/inteiroTeor/ pesquisarlnteiroTeor.asp>. Acesso em: 02 nov. 2014.

73 BRASIL. Supremo Tribunal Federal. ADI n. 3510. Relator: Ministro Carlos Britto. Diário da Justiça da União, Brasília, DF, 29 maio 2008. Disponível em: <http://www.stf.jus.br/portal/inteiroTeor/ pesquisarlnteiroTeor.asp>. Acesso em: 02 nov. 2014.

74 BRASIL. Supremo Tribunal Federal. ADI n. 3510. Relator: Ministro Carlos Britto. Diário da Justiça da União, Brasília, DF, 29 maio 2008. Disponível em: <http://www.stf.jus.br/portal/inteiroTeor/ pesquisarlnteiroTeor.asp>. Acesso em: 02 nov. 2014 
nos princípios igualmente constitucionais da dignidade da pessoa humana e da paternidade responsável. ${ }^{75}$

No acórdão, restaram reconhecidos o direito constitucional à liberdade de expressão científica e a lei de biossegurança como densificação dessa liberdade. Consta expressamente da decisão:

[...] que o termo 'ciência', enquanto atividade individual, faz parte do catálogo dos direitos fundamentais da pessoa humana (inc. IX do art. 5ำ da CF). E a liberdade de expressão se afigura como clássico direito constitucional-civil ou genuíno direito de personalidade. Assim merece o máximo de proteção jurídica, até como signo de vida coletiva civilizada. Tão qualificadora do indivíduo e da sociedade é essa vocação para os misteres da ciência que o Magno Texto Federal abre todo um autonomizado capítulo para prestigiá-la por modo superlativo (capítulo de no IV do título VIII). ${ }^{76}$

A Ministra Carmem Lúcia referiu no seu voto, afastando qualquer dúvida, que "a dignidade da pessoa humana, prevista na Constituição Federal, dota o bloco normativo, posto no art. 5ำ da Lei nำ11.105/2005, do necessário fundamento para dele afastar qualquer invalidade jurídica".

Para o STF, o art. 5ำ da Lei de Biossegurança, para além de não violar o princípio da dignidade da pessoa humana quando permite a fertilização de embriões in vitro e a pesquisa em células-tronco para fins terapêuticos, acaba sendo uma manifestação de tal princípio, porquanto permite o planejamento familiar e a proteção dos direitos fundamentais à vida e à saúde.

O princípio da dignidade da pessoa humana, nessa decisão, acabou sendo aplicado concomitantemente com outros direitos fundamentais de primeira dimensão, como o direito à vida, e de segunda, como o direito à saúde. 0 princípio, como demonstrado na decisão, é mais do que mero norte hermenêutico na aplicação e na ponderação dos direitos fundamentais previstos na Constituição: é um balizador que evita uma aplicação desproporcional e excessiva do princípio da precaução na pretensa tutela dos direitos à vida e à saúde quando confrontados

75 BRASIL. Supremo Tribunal Federal. ADI n. 3510. Relator: Ministro Carlos Britto. Diário da Justiça da União, Brasília, DF, 29 maio 2008. Disponível em: <http://www.stf.jus.br/portal/inteiroTeor/ pesquisarlnteiroTeor.asp>. Acesso em: 02 nov. 2014.

76 BRASIL. Supremo Tribunal Federal. ADI n. 3510. Relator: Ministro Carlos Britto. Diário da Justiça da União, Brasília, DF, 29 maio 2008. Disponível em: <http://www.stf.jus.br/portal/inteiroTeor/ pesquisarlnteiroTeor.asp>. Acesso em: 02 nov. 2014. 
com importantes pesquisas científicas com células-tronco, ${ }^{77}$ que podem salvar milhares de vidas e, também, permitir que casais celebrem o direito à vida com as fertilizações in vitro, realizando, desse modo, um racional planejamento familiar tutelado pelo próprio texto constitucional.

Um dos mais polêmicos julgamentos do STF, contudo, foi a ADI o $4.277,,^{78}$ que teve como relator o Ministro Ayres Britto, discutindo a equiparação das uniões estáveis entre casais heterossexuais e homossexuais, o chamado casamento gay. Vários grupos religiosos, como significativa parte da sociedade brasileira, por questões religiosas e na defesa de posições morais, manifestaram forte oposição ao reconhecimento por parte do Estado da proteção legal para a união estável entre as pessoas do mesmo sexo.

Em face da secularização, marcada pela separação entre Estado e religião, era intuitivo que um debate jurídico, tendo por fundamento a autonomia do ser humano, permeado por razões morais, chegasse ao Supremo Tribunal Federal com esse tema específico. Foi o que ocorreu. O princípio da dignidade da pessoa humana foi abordado várias vezes, de modo expresso ou não, nesse leading case.

A decisão do STF foi no sentido de conferir uma interpretação ao art. 1.723 do Código Civil, com a aplicação da "técnica da interpretação conforme", para a "exclusão do dispositivo de qualquer significado que impeça o reconhecimento da união contínua, pública e duradoura entre pessoas do mesmo sexo como família" para que exista "o reconhecimento segundo as mesmas regras e com as mesmas consequências da união estável heteroafetiva". ${ }^{79}$

Constou da ementa do acórdão o reconhecimento do direito à preferência sexual como uma direta emanação do princípio da "dignidade da pessoa humana". Foi mencionado, ainda, como decorrência o direito à autoestima no mais elevado ponto da consciência do indivíduo e componente de sua dignidade. Restaram

77 Michael Sandel refere que, "em vez de banir as pesquisas com células-tronco embrionárias e a clonagem para fins de pesquisa, deveríamos pemitir sua continuidade sob regulações que englobem as restrições morais adequadas ao mistério da vida humana. Tais regulações deveriam incluir a proibição da clonagem humana para fins de reprodução; limites razoáveis à extensão de tempo que um embrião pode ser cultivado em laboratório; exigências para emitir licenças para clínicas de fertilidade; restrições quanto à transformação de óvulos e espermatozoides em comodities e criação de um banco de células-tronco para evitar que os interesses de patentes monopolizem o acesso à pesquisa com células-tronco. Essas medidas, ao que me parece, oferecem as melhores esperanças para evitar o uso descontrolado da vida humana incipiente e tornar o progresso da biomedicina uma benção para a saúde, não mais um episódio da erosão de nossas sensibilidades humanas" (SANDEL, Michael. The case against perfection. Cambridge: Harvard University Press, 2007. p. 134).

78 BRASIL. Supremo Tribunal Federal. Ação Direta de Inconstitucionalidade n. 4.277/DF. Relator: Ministro Carlos Britto. Diário de Justiça da União, Brasília, DF, 14 out. 2011. Disponível em: <http://redir.stf.jus. $\mathrm{br} /$ paginadorpub/paginador.jsp?docTP=AC\&doclD=628635>. Acesso em: 02 nov. 2014.

79 BRASIL. Supremo Tribunal Federal. Ação Direta de Inconstitucionalidade n. 4277/DF. Relator: Ministro Carlos Britto. Diário de Justiça da União, Brasília, DF, 14 out. 2011. Disponivel em: <http://redir. stf.jus. $\mathrm{br} /$ paginadorpub/paginador.jsp?docTP=AC\&docID=628635>. Acesso em: 02 nov. 2014. 
consagrados no julgado o "direito da busca da felicidade e o salto normativo da proibição do preconceito para a proclamação do direito à liberdade sexual”. ${ }^{80}$

Importante ressaltar que, para o STF, "o concreto uso da sexualidade faz parte da autonomia da vontade das pessoas naturais", sendo que o "empírico uso da sexualidade" é realizado "nos planos da intimidade e da privacidade constitucionalmente tuteladas". Restou consignado no julgamento que "a Constituição de 1988, ao utilizar-se da expressão 'família', não limita sua formação a casais heteroafetivos". ${ }^{81}$

O princípio da dignidade da pessoa humana aplicado em conjunto com o direito fundamental à igualdade e à tutela da família, como dever do Estado, foi fundamental por assegurar proteção jurídica às relações entre pessoas que optaram por relacionar-se com outras do mesmo sexo. Não há dúvida de que o direito à felicidade, à segurança e a uma vida boa não pode ser sonegado aos seres humanos que optaram por relacionar-se afetivamente com outras independentemente do gênero, sob pena de violação do princípio da dignidade da pessoa humana. A aplicação equitativa e proporcional desse princípio, sob pena de incidência da proteção insuficiente, deve ser cega quanto à opção sexual dos cidadãos para fins de tutela estatal.

O desenvolvimento humano marcado pela necessária tutela constitucional consubstanciada pelo reconhecimento da máxima eficácia dos direitos fundamentais em todas as suas dimensões deve ser garantido pelo Estado. Com a omissão dos Poderes Executivo e Legislativo na promoção de políticas públicas que promovam e respeitem a dignidade da pessoa humana, cabe ao Estado-Juiz assegurar a supremacia da Constituição e a garantia mais ampla do desenvolvimento humano. Sem o respeito à dignidade da pessoa humana, não existe desenvolvimento humano. Cabe ao STF, na sua função de guardião da Constituição, salvaguardar esse princípio.

Importa referir, porém, que "raramente a dignidade é o fundamento central do argumento e, menos ainda, tem o seu conteúdo explorado ou explicitado"82 nas decisões, o que não retira do princípio a sua grande importância dentro do Estado Democrático e Social de Direito. Impossível, pois, se conceber o direito

80 BRASIL. Supremo Tribunal Federal. Ação Direta de Inconstitucionalidade n. 4277/DF. Relator: Ministro Carlos Britto. Diário de Justiça da União, Brasília, DF, 14 out. 2011. Disponível em: <http://redir.stf.jus. $\mathrm{br} /$ paginadorpub/paginador.jsp?docTP=AC\&doclD=628635>. Acesso em: 02 nov. 2014.

81 BRASIL. Supremo Tribunal Federal. Ação Direta de Inconstitucionalidade n. 4277/DF. Relator: Ministro Carlos Britto. Diário de Justiça da União, Brasília, DF, 14 out. 2011. Disponível em: <http://redir.stf.jus. $\mathrm{br} /$ paginadorpub/paginador.jsp?docTP=AC\&doclD=628635>. Acesso em: 02 nov. 2014.

82 BARROSO, Luís Roberto. A dignidade da pessoa humana no direito contemporâneo: a construção de um conceito à luz da jurisprudência. Belo Horizonte: Fórum, 2013. p. 122. 
fundamental ao desenvolvimento sustentável negligenciando o princípio da dignidade da pessoa humana.

\section{Dignidade da pessoa humana e desenvolvimento sustentável}

Não existe direito fundamental ao desenvolvimento sustentável sem o respeito ao princípio da dignidade da pessoa humana, que promove e estimula a inclusão social. Observa-se que existe, nos países em desenvolvimento, como o Brasil, desequilíbrio entre desenvolvimento econômico, desenvolvimento humano, proteção ambiental e governança. A dignidade da pessoa humana, nesse cenário de insustentabilidade, acaba por ser violada.

Consequência dessa crise no desenvolvimento atingiu imensa reação popular nos protestos de junho de 2013. Segundo Castells, o movimento do passe livre "passou ao clamor pela liberdade em todas as suas dimensões e surgiu das entranhas de um país perturbado por um modelo de crescimento que ignora a dimensão humana e ecológica do desenvolvimento". ${ }^{83}$ Megaprotestos que levaram ao impeachment da Presidente Dilma Rousseff marcaram os anos de 2015 e 2016 e foram motivados por fatores de insatisfação com o processo de desenvolvimento, como: serviços de saúde e educação (aspecto humano); retorno da inflação, baixo crescimento do PIB e alta do dólar (aspecto econômico); casos do Mensalão e do Petrolão, o último investigado pela operação Lava-Jato, que atingiu altos próceres do partido governista, dos partidos da base aliada e grandes empreiteiros (aspecto da governança).

Schumpeter, a respeito do desenvolvimento e da eclosão de crises nesse processo, refere que o "método de cura [para as crises] é o melhoramento do prognóstico das conjunturas", 84 o que pode ocorrer apenas no contexto de um horizonte mais largo e não imediatista. Deve o gestor público estruturar políticas de desenvolvimento com visão de longo prazo, como imperativo da sustentabilidade. ${ }^{85}$

83 CASTELLS, Manuel. Redes de indignação e esperança: movimentos sociais na era da internet. Rio de Janeiro: Zahar, 2013. p. 183.

84 SCHUMPETER, Joseph. The theory of economic development. New Brunswick: Transaction Publishers, 1983. p. 523-525.

85 Refere Juarez Freitas que "o desenvolvimento e a sustentabilidade não apenas são compatíveis, mas se constituem mutuamente. Exatamente por isso, contemplada uma lógica bem distinta da dominante, devem ser incrementados... aqueles financiamentos de longo prazo à economia verde, com os estímulos competentes à implantação concreta do novo paradigma" (FREITAS, Juarez. Sustentabilidade: direito ao futuro. 3. ed. Belo Horizonte: Fórum, 2016. p. 110). 
Importante, noutro sentido, bem avaliar a distribuição de bens - não pecuniários, mas vinculados ao desenvolvimento do ser humano - e o acesso que as pessoas têm a serviços adequados - de saúde e educação - e à justiça. E, com igual importância, se estão presentes as liberdades religiosa, sexual, de ação política e de expressão nos debates públicos no seio da comunidade.

Vem bem a calhar, nesse tema, as palavras de Aristóteles: “É evidente que a riqueza não é o bem que procuramos, pois é meramente útil e em proveito de alguma outra coisa". ${ }^{86}$ A riqueza financeira de uma nação não é bastante em si mesma se o desenvolvimento humano e o princípio da dignidade da pessoa humana forem negligenciados. Pode a riqueza até promover aspectos do desenvolvimento humano, mas deve ser bem distribuída para que todos tenham acesso ao mínimo de renda que proporcione uma existência digna ou o mínimo social para os indivíduos proposto por Rawls.

A inclusão social só pode ser alcançada com a observância pelo Estado e por particulares do direito que possuem as pessoas ao respeito enquanto titulares de dignidade. Deve ser assegurada por políticas públicas não apenas de governo, mas de Estado, visando não somente ao direito das presentes, mas das futuras gerações, conformadas pelo princípio da sustentabilidade. ${ }^{87}$

Entretanto, não é demais dar-se especial atenção à advertência exposta por Trubek e Galanter no sentido de que os estudiosos do direito e do desenvolvimento começaram a perceber que, mesmo em sociedades desenvolvidas, como os Estados Unidos, a neutralidade formal do sistema jurídico não é incompatível com o uso do direito como ferramenta para fomentar a dominação das elites. Isso ocorre porque os grupos mais abastados e conservadores da sociedade têm, frequentemente, melhor acesso ao sistema jurídico ${ }^{88}$ e mais força e poder de barganha no Congresso para a aprovação de leis excludentes e fomentadoras de processos de desenvolvimento que causam poluição e concentração de renda, sem permitir mobilidade social para os setores mais desaquinhoados da sociedade.

86 ARISTOTLE. Nicomachean ethics. Oxford: Oxford University Press, 1980. p. 7.

87 Como enfatiza Mariana Figueiredo: “Quer em sua dimensão estrita, quando simplesmente designado como princípio da sustentabilidade, quer no tríplice vértice ecológico, econômico e social que se concilia num princípio do desenvolvimento sustentável, conclui-se que se tem aqui norma jurídica, a viger como novo parâmetro de aferição e conformação das políticas públicas, antes de tudo, ao compromisso com a garantia de condições minimamente adequadas à vida digna e com qualidade, ou seja, à proteção e [à] realização do mínimo existencial, individual e coletivamente, e, num olhar prospectivo, à realização da justiça intergeracional, isto é, a justiça social hoje e para o futuro" (FIGUEIREDO, Mariana. O sistema único de saúde e o princípio da sustentabilidade: interconexões e perspectivas acerca da proteção constitucional da saúde. 2013. Tese (Doutorado em Direito) - Faculdade de Direito, Pontifícia Universidade Católica do Rio Grande do Sul, Porto Alegre, 2013. Disponível em: <http://repositorio.pucrs.br/dspace/ bitstream/10923/2514/1/0004 49234-Texto\%2BParcial-0.pdf>. Acesso em: 20 jun. 2014).

88 TRUBEK, David; GALANTER, Mark. Scholars in self-estrangement: some reflections on the crisis in law and development studies in the United States. Wisconsin Law Review, Madison, WI, n. 4, p. 1095, 1974. 
Aumentar a racionalidade instrumental do processo de desenvolvimento somado à regulação econômica "pode contribuir para o bem-estar econômico de uma pequena elite, sem alterar a situação da massa da população, ou até mesmo mudar sua situação para pior". 89

$\mathrm{Na}$ abordagem do tema direito e desenvolvimento, o conceito de países desenvolvidos e em desenvolvimento, ${ }^{90}$ com extremas desigualdades, precisa ser levado a sério pela comunidade global. Essa preocupação internacional referente ao desenvolvimento desequilibrado das nações precisa levar a sério a necessidade da criação de diplomas legais de referência no que tange ao direito ao desenvolvimento sustentável integrado ao princípio da dignidade da pessoa humana.

O direito internacional ao desenvolvimento é parte integrante dos direitos humanos, sendo, pois, inderrogável e imprescritível, possuindo como titular o indivíduo, cabendo aos Estados e aos demais entes da sociedade civil, nacional e internacional, a responsabilidade solidária por sua promoção e garantia, estando fundado no consenso dos povos e das nações. Suas fontes estão calcadas nos tratados, nas convenções, nos costumes e nas resoluções das organizações internacionais, em particular aquelas oriundas da ONU. ${ }^{91}$

De fato, a Carta Internacional de Direitos Humanos é composta pela Declaração Universal de Direitos Humanos e pelos dois pactos: o Pacto Internacional sobre Direitos Civis e Políticos ${ }^{92}$ e o Pacto Internacional sobre Direitos Econômicos, Sociais e Culturais. ${ }^{93}$ As disposições desses tratados referentes ao desenvolvimento não se resumem apenas a questões econômicas, ${ }^{94}$ já que estão

89 TRUBEK, David; GALANTER, Mark. Scholars in self-estrangement: some reflections on the crisis in law and development studies in the United States. Wisconsin Law Review, Madison, WI, n. 4, p. 1096, 1974.

90 Embora a obra seja antiga, parece que as palavras de Galeano possuem valia nos dias atuais no sentido de que "os preços da maioria dos produtos que a América Latina vende baixam implacavelmente em relação aos preços dos produtos que compra dos países que monopolizam a tecnologia, o comércio, o investimento e o crédito" (GALEANO, Eduardo. Las venas abiertas de America Latina. México: Siglo XXI, 1971. p. 132).

91 FERREIRA, Lier Pires. Direito Internacional, petróleo e desenvolvimento. São Paulo: Saraiva, 2011. p. 343.

92 Adotado pela Resolução no 2.200-A da Assembleia Geral das Nações Unidas, em 16 de dezembro de 1966. Aprovado pelo Decreto Legislativo ํㅜ 226, de 12 de dezembro de 1991. Ratificado pelo Brasil em 24 de janeiro de 1992. Em vigor no Brasil desde 24 de abril de 1992. Promulgado pelo Decreto n 592, de 06 de julho de 1992.

93 Aprovado pelo Decreto Legislativo no 226, de 12 de dezembro de 1991. Assinado pelo Brasil em 24 de janeiro de 1992. Entrou em vigor no Brasil em 24 de abril de 1992. Promulgado pelo Decreto n 591, de 06 de julho de 1992.

94 RAMOS, André de. Teoria geral dos direitos humanos na ordem internacional. Rio de Janeiro: Renovar, 2005. p. 65. 
focadas no desenvolvimento humano ligado diretamente ao princípio da dignidade da pessoa humana. ${ }^{95}$

Em matéria de convenções internacionais dos direitos humanos relacionadas com o direito ao desenvolvimento humano, são importantes referências: a Convenção sobre a Eliminação de Todas as Formas de Discriminação Contra a Mulher, a Convenção sobre o Direito da Criança; a Convenção sobre a Proteção e a Promoção da Diversidade das Expressões Culturais, que destaca a necessidade de incorporar a cultura como elemento estratégico das políticas de desenvolvimento nacionais e internacionais, bem como a cooperação internacional para o desenvolvimento, considerando igualmente a Declaração do Milênio das Nações Unidas, com sua ênfase na erradicação da pobreza. ${ }^{96}$

Igualmente, são dignas de nota a Convenção Internacional sobre a Eliminação e Repressão do Crime de Apartheid, a Convenção sobre a Luta contra a Discriminação no Campo do Ensino da UNESCO, bem como as Convenções $n^{-}$ 122, 143 e 169 da Organização Internacional do Trabalho. ${ }^{97}$

Do campo internacional para o âmbito interno, a Constituição Federal de 1988 não negligenciou o desenvolvimento humano; antes pelo contrário, vinculou-o expressamente ao princípio da dignidade da pessoa humana, seguindo a referida e citada tendência exposta pelos diplomas legais internacionais.

A Carta Política brasileira prevê expressamente como um dos seus objetivos fundamentais, no art. 3o, inc. II, “garantir o desenvolvimento nacional”. É relevante verificar que o Constituinte de 1988 , no mesmo artigo, previu como objetivos igualmente fundamentais: I - construir uma sociedade livre, justa e solidária; III erradicar a pobreza e a marginalização e reduzir as desigualdades sociais e regionais; e IV - promover o bem de todos, sem preconceitos de origem, raça, sexo, cor, idade e quaisquer outras formas de discriminação. Não existe dúvida de que esses dispositivos precisam de uma interpretação conjunta que não pode levar a outra conclusão que não seja a de erigir o desenvolvimento sustentável (na sua dimensão humana) como um dos princípios fundamentais da Constituição Federal de 1988.

95 Anjos Filho enfatiza que os dois pactos internacionais referidos “[...] mencionam já no preâmbulo a dignidade humana, a igualdade entre todos e a inalienabilidade dos direitos como fundamentos da liberdade, da justiça e da paz e, neste sentido, que o ideal do ser humano livre e liberto do temor e da miséria não pode ser realizado a menos que se criem condições que permitam a cada um gozar de seus direitos econômicos, sociais e culturais, assim como seus direitos civis e políticos, o que revela um nítido comprometimento com a indivisibilidade dos direitos humanos" (ANJOS FILHO, Robério Nunes dos. Direito ao desenvolvimento. São Paulo: Saraiva, 2013. p. 168).

96 ANJOS FILHO, Robério Nunes dos. Direito ao desenvolvimento. São Paulo: Saraiva, 2013. p. 173.

97 ANJOS FILHO, Robério Nunes dos. Direito ao desenvolvimento. São Paulo: Saraiva, 2013. p. $174-175$. 
A ordem econômica e financeira, fundada na valorização do trabalho humano e na livre iniciativa, tem por fim assegurar a todos existência digna, conforme os ditames da justiça social, como expressamente previsto no art. 170 da Constituição Federal. ${ }^{98}$

O conceito de justiça social, que promove o desenvolvimento, é o "que significa a superação das injustiças na repartição, em nivel pessoal, do produto econômico" e que "as correções na injustiça da repartição deixam de ser apenas uma imposição ética, passando a consubstanciar exigência de qualquer política econômica capitalista". ${ }^{99}$

O princípio da dignidade humana está umbilicalmente ligado ao direito fundamental ao desenvolvimento sustentável e ao seu pilar de inclusão social, seja como um mecanismo de interpretação, seja para emprestar eficácia e densificar o direito fundamental ao desenvolvimento sustentável nas suas dimensões ambiental, econômica, de governança e inclusão social.

A liberdade de expressão e as garantias individuais próprias da democracia são fundamentais para que a sociedade possa, dentro de um debate público, construir políticas públicas fundamentadas no princípio da dignidade da pessoa humana para reduzir as desigualdades, as discriminações e garantir a todos uma vida boa em comunidade, que possa propiciar o desenvolvimento sustentável no seu estágio mais avançado.

\section{Conclusão}

A noção de dignidade humana é antiga. No início, houve uma manifesta confusão entre o poder temporal e o espiritual, como demonstram trechos da Bíblia e do Alcorão. Após longa evolução, foi no lluminismo, em especial com o pensamento kantiano, que as noções de liberdade e de autonomia passaram a considerar o homem como um fim em si mesmo. Após as duas guerras mundiais, a comunidade internacional e as nações, por meio das constituições, passaram a prever expressamente a dignidade da pessoa humana como valor e princípio. Precedentes jurisprudenciais das mais diversas democracias ocidentais passaram

98 Como refere Grau: “[...] a ordem econômica tem por fim assegurar a todos existência digna, conforme os ditames da justiça social. Na referência a ela, a consagração de princípio constitucionalmente conformador (Canotilho). O princípio da justiça social conforma a concepção de existência digna cuja realização é o fim da ordem econômica e compõe um dos fundamentos da República Federativa do Brasil (art. 1ํㅡ, inc. III)" (GRAU, Eros Roberto. Comentário ao art. 170 da CF/1988. In: CANOTILHO, José Joaquim Gomes et al. (Coord.). Comentários à constituição do Brasil. São Paulo: Saraiva: Almedina, 2013. p. 1794).

99 GRAU, Eros Roberto. Comentário ao art. 170 da CF/1988. In: CANOTILHO, José Joaquim Gomes et al. (Coord.). Comentários à constituição do Brasil. São Paulo: Saraiva: Almedina, 2013. p. 1794. 
a reconhecer e a densificar o princípio da dignidade da pessoa humana ao analisar casos em concreto. No Brasil, o princípio restou consagrado pela Constituição Federal de 1988 e tem sido aplicado pelo Supremo Tribunal Federal em conjunto com outros direitos fundamentais negativos e prestacionais.

Impossivel negar que o princípio da dignidade da pessoa humana está relacionado intimamente com o direito fundamental ao desenvolvimento sustentável. Não existe direito ao desenvolvimento sustentável tutelado pela Constituição que possa ir de encontro ao princípio da dignidade da pessoa humana. O direito fundamental ao desenvolvimento sustentável na dimensão da inclusão social não poderá ser alcançado se depender exclusivamente dos direitos fundamentais prestacionais. É importante que o princípio da dignidade da pessoa humana norteie o desenvolvimento sustentável com a finalidade de diminuição das desigualdades sociais, políticas e econômicas que têm aumentado em escala global nos últimos séculos, como bem afirmado por Stiglitz em A Grande Divisão. ${ }^{100}$ O grande desafio do Estado na busca da concretização do direito fundamental ao desenvolvimento sustentável, orientado pelo princípio da dignidade da pessoa humana, precisará passar, para além da busca da máxima eficácia dos direitos fundamentais no sentido tradicional, pelo desenvolvimento humano em sentido estrito.

\section{Sustainable development as fundamental right and the human dignity principle}

Abstract: The article brings up the principle of human dignity and its historical evolution since the dawn of mankind, through the Middle Ages, Modernity and Post-Modernity. The principle is critically analyzed based on longstanding foreign doctrine and jurisprudence for only then being evaluated based on national doctrine against the background of leading cases of the Supreme Court. Parameters set, the principle of human dignity is pointed out as relevant to the achievement of the fundamental right to sustainable development in its human pillar (social inclusion). It is emphasized that in developing countries, like Brazil, there is an imbalance between economic development, human development, environmental protection and governance. The principle of human dignity in this scenario of nonsustainability always ends up being essential in promoting development. The thesis argued in the paper, as supported in national and foreign doctrine and jurisprudence, is that there is no fundamental right to sustainable development capable to achieve, without respect for the guiding principle of human dignity, which promotes and encourages social inclusion and performs as a promoter and guarantor of fundamental rights.

Keywords: Constitutional Law. Principle. Human Being Dignity. Law and Development.

Summary: 1 Introduction - 2 Human dignity and historical development - $\mathbf{3}$ Human dignity in the overseas jurisprudence $\mathbf{-} \mathbf{4}$ Human dignity according to Federal Constitution of $1988-\mathbf{5}$ The STF jurisprudence on human dignity $-\mathbf{6}$ Human dignity and sustainable development $-\mathbf{7}$ Conclusion References

100 STIGLITZ, Joseph. The great divide: unequal societies and what we can do about them. New York: W.W. Norton \& Companhy, 2015. 


\section{Referências}

ACKERMAN, Bruce. We the people: the civil rights revolution. Cambridge: The Belknap Press of Harvard University, 2014. 3v.

ALCORÃO Sagrado. São Paulo: Folha de São Paulo, 2010. (Coleção Folha: livros que mudaram o mundo, v. 19).

ANJOS FILHO, Robério Nunes dos. Direito ao desenvolvimento. São Paulo: Saraiva, 2013.

ARISTOTLE. Nicomachean ethics. Oxford: Oxford University Press, 1980.

BARROSO, Luís Roberto. A dignidade da pessoa humana no direito contemporâneo: a construção de um conceito à luz da jurisprudência. Belo Horizonte: Fórum, 2013.

BARROSO, Luís Roberto. Da falta de efetividade à judicialização excessiva: direito à saúde, fornecimento gratuito de medicamentos e parâmetros para a atuação judicial. Interesse Público - IP, Belo Horizonte, ano 9, n. 46, p. 01-37, 2007.

BOSSELMANN, Klaus. The principle of sustainability: transforming law and governance. Farnham: Ashgate, 2008.

CASTELLS, Manuel. Redes de indignação e esperança: movimentos sociais na era da internet. Rio de Janeiro: Zahar, 2013.

BÍBLIA. Português. Bíblia sagrada. São Paulo: Folha de São Paulo, 2010. (Coleção Folha: livros que mudaram o mundo, v. 18).

CARTA dos direitos fundamentais da União Europeia. Jornal Oficial das Comunidades Europeias, [S.I.], 18 dez. 2000. Disponível em: <http://www.europarl.europa.eu/charter/ pdf/text_pt.pdf>. Acesso em: 01 maio 2016.

CATROGA, Fernando. Entre Deuses e Césares: secularização, laicidade e religião civil. Coimbra: Almedina, 2006.

COMPARATO, Fábio Konder. A afirmação histórica dos direitos humanos. São Paulo: Saraiva, 1999.

COULANGES, Fustel. A cidade antiga: estudo sobre o culto, o direito e as instituições da Grécia Antiga e de Roma. São Paulo: Bauru, 2009.

CRETELLA JÚNIOR, José. Curso de direito romano. 15. ed. Rio de Janeiro: Forense, 1993. DWORKIN, Ronald. Taking rights seriously. Cambridge: Harvard University Press, 1977.

FERREIRA, Lier Pires. Direito Internacional, petróleo e desenvolvimento. São Paulo: Saraiva, 2011.

FIGUEIREDO, Mariana. O sistema único de saúde e o princípio da sustentabilidade: interconexões e perspectivas acerca da proteção constitucional da saúde. 2013. Tese (Doutorado em Direito) - Faculdade de Direito, Pontifícia Universidade Católica do Rio Grande do Sul, Porto Alegre, 2013. Disponível em: <http://repositorio.pucrs.br/dspace/ bitstream/10923/2514/1/0004 49234-Texto\%2BParcial-0.pdf>. Acesso em: 20 jun. 2014. 
FREITAS, Juarez. Sustentabilidade: direito ao futuro. 3. ed. Belo Horizonte: Fórum, 2016. GALEANO, Eduardo. Las venas abiertas de America Latina. México: Siglo XXI, 1971.

GUNTHER, Gerald; SULLIVAN, Kathleen. Constitutional law. 13th ed. New York: The Fondation Press, 1997.

GRAU, Eros Roberto. Comentário ao art. 170 da CF/1988. In: CANOTILHO, José Joaquim Gomes et al. (Coord.). Comentários à constituição do Brasil. São Paulo: Saraiva: Almedina, 2013.

KANT, Immanuel. A metafísica dos costumes. São Paulo: Folha de São Paulo, 2010.

MILL, John Stuart. On liberty and other writings. London: Cambridge Univesity Press, 2012. MILL, John Stuart; BENTHAM, Jeremy. Utilitarianism and other essays. London: Penguin, 2004. MIRANDOLA, Giovanni Pico Della. A dignidade do homem. Lisboa: Edições 70, 1986.

MIRANDOLA, Giovanni Pico Della. Oratio de hominis dignitate. Disponível em: <http://www. wsu.edu:8080 wldciv/world_civ_reader_1/pico.html>. Acesso em: 01 jan. 2016.

NOVAES, Jorge Reis. Direitos fundamentais e justiça constitucional: em Estado de direito democrático. Coimbra: Coimbra, 2010.

POSNER, Richard. Divergent paths. The academy and the judiciary. Cambridge: Harvard University Press, 2016.

POSNER, Richard. Reflections on judging. Cambridge: Harvard University Press, 2013. p. 329-350.

RAMOS, André de. Teoria geral dos direitos humanos na ordem internacional. Rio de Janeiro: Renovar, 2005.

RIDOLA, Paolo. A dignidade humana e o "princípio liberdade" na cultura constitucional européia. Porto Alegre: Livraria do Advogado, 2014.

SANDEL, Michael. Justice: what's the right thing to do? New York: Farrar, Straus and Giroux, 2009.

SANDEL, Michael. Liberalism and the limits of justice. 2nd ed. Cambridge: Cambridge University Press, 1998.

SANDEL, Michael. What's money can't buy? The moral limits of market. New York: Farrar, Straus and Giroux, 2012.

SANDEL, Michael. The case against perfection. Cambridge: Harvard University Press, 2007.

SARLET, Ingo. Comentários ao art. 1, inc. III, da CF/88. In: CANOTILHO, J. J. Gomes et al. (Coord.). Comentários à Constituição do Brasil. São Paulo: Saraiva: Almedina, 2013.

SARLET, Ingo. Dignidade da pessoa humana e direitos fundamentais na Constituição Federal de 1988. 9. ed. Porto Alegre: Livraria do Advogado, 2012.

SARLET, Ingo. A eficácia dos direitos fundamentais: uma teoria geral dos direitos fundamentais na perspectiva constitucional. 12. ed. Porto Alegre: Livraria do Advogado, 2015. 
SARLET, Ingo; FENSTERSEIFER, Tiago. Direito constitucional ambiental. 4. ed. São Paulo: Revista dos Tribunais, 2014.

SCHUMPETER, Joseph. The theory of economic development. New Brunswick: Transaction Publishers, 1983.

STONE, Geoffrey et al. Constitutional law: keyed to courses using. 6th ed. New York: Wolters Kluwer, 2010.

SUNSTEIN, Cass. Laws of fear. beyond the precautionary principle. New York: Cambridge Press, 2005.

SUNSTEIN, Cass. The arithmetic of arsenic, 90. Georgetown Law Review, Washington, n. 2255, p. 2261-2263, 2002.

SUNSTEIN, Cass. Worst-case scenarios. Cambridge: Harvard University Press, 2007.

WEBER, Thadeu. Ética e filosofia política: Hegel e o formalismo kantiano. 2. ed. Porto Alegre: Edipucrs, 2009.

WEDY, Gabriel. O princípio constitucional da precaução como instrumento de tutela do meio ambiente e da saúde pública. Belo Horizonte: Interesse Público, 2009.

WEDY, Gabriel. As uniões homoafetivas e o preconceito. O Sul, Porto Alegre, 18 ago. 2013. Caderno de Colunistas, p. 3.

TRUBEK, David; GALANTER, Mark. Scholars in self-estrangement: some reflections on the crisis in law and development studies in the United States. Wisconsin Law Review, Madison, WI, n. 4, p. 1095, 1974.

UNESCO. Declaração universal dos direitos humanos. Brasília, DF: UNESCO, 1998. Disponível em: <http://unesdoc.unesco.org/images/0013/001394/139423por.pdf>. Acesso em: 02 out. 2015.

Submetido: 02.02.2017

Pareceres: 08.04.2017, 18.01.2018

Aprovado: 24.01.2018 